ルおよび第 1 級アミンの分子について沸点を左右する諸 要素を追求㭘討したが，ててに都者は分子運動に際して 単位筫量当りの力学的条件をはほ等しくしている液体を 選定し，てれによって液体の沸点と分子の質量および密 度との間の原則的な関係を求め，乙の結楽分子の単位資 堅の笑容積が等しく，かつ分子運動に際しての分子の摩 擦保数および安定庭が等しいときは，液体の沜点とてれ ら諸要素との間には次式のような一つの規倠のあるてと を知った。しかし式中 $M, T, \rho$ および $t$ はそれぞれ 分子量, 沸点の摄氏温度, 密度およびその密度をもつと きの液体の提氏温度である。

$$
M \rho^{2}=k(T-t)
$$

$k:$ 比例定数

そして分子の単位筫量の笑容積および力学的条件をほ ほ等しくしている浓体の比例定数 $k$ の值は，第 1 表ない し第4 表にはほ点線を㜔としてそれ以下に揭げたが，て れらの表中に見られる分子の力学的状熊の相違を示す $k$ の変化の推移は，との関係を得るために行った第 1 報お よび第 2 報の結論とほとんど合致する。

本一連の破労に際し終始御想篤なる御指導を睗わった 本学浜村保次教授に深く感謝の意を表子る。

（神戶大学理学部化学教综，神戶市東鹳区）（昭和 30 年 6 月 17 日受理）

\title{
石灰石中に含まれる微量マグネシゥムの存在状慜（その 1３）
}

北野康

\section{（その 1） 存在状態の新決定法}

\section{緒}

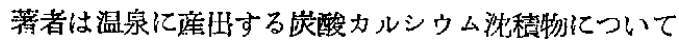
化学的研究を行い，得られた結果についてはその都度報 告りしてきた。淡積物に含まれる徽量元素の存在状態は 生成系の状態によって定まると考光られ，また風化によ る元素の移動にも重大な影響を与えるととは明らかであ る。すなわち沈積物の微量成分の含有量と微量成分の存 在形とは大きな関連がある。天然に座㫫する炭陵カルシ ウムが生成された環境，条件等を厳密に知ることは地球 化学的にみて重要な慧昧がある。現在までに著者は主成

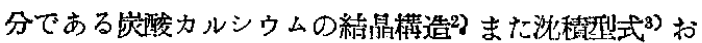
よび化学成分》等を知ることによって生成持の環境を明 らかにする知識か得られるととを報告してきたが，微量

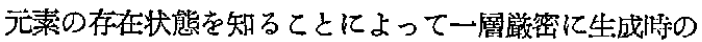
環境を知るととができると予想される。そこでツ上述べ たような目的で著者は天然産石灰石中の微量マグネシウ ムの存在状熊を浃定しようと武みて成功したので，とし にその新浃定法について報告する。徉来はごく微量のマ グネシゥムの存在状態の決定は不可能であった。

1) 北野, 本就 74, 380 (1953); 74, 789 (1953); 75, 125 (1954); 75,129 (1954); 76, 582 (1955).

2) 北野, 本諾 76, 582 (1955).

3) 北野, 本誌 74, 380 (1953); 74, 789 (1953).

4) 北野, 本梽 75, 125 (1954).

\section{方 針}

一般に天然産石灰石の分析絬果 ${ }^{5}$ から石灰石中のマグ ネシウムは炭酸塩として入っていると考光られる。こう 考えるとマグネシウムは宸酸マグネシウム*1かドロマイ 卜 $\mathrm{CaMg}\left(\mathrm{CO}_{3}\right)_{2}$ として存在すると一般には考光られ る*。なぜるらば炭酸カルシウム中のカルシウムの任意 の場所にマグネシウムが入りとむととは結晶学上からは 一般には考え難くある定った場所に入りやすいからであ

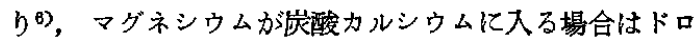
マイトか炭酸マグネシウムかのいずれかの形で入ってい る場合が大部分だと考えてよい。したがってどく微量の マグネシウムの存在状態を涣定するためにはマグネシウ ムがドロマイトとして入っているか，炭酸マグネシウム として入っているかをまずとこでは決定するという比輘

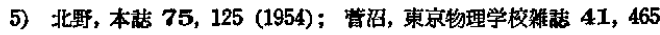
(1932); F. W. Clarke, "The Data of Geochemistry" p. 564 (1924) Washington 等参想. マグネシゥムは大体酸化マ グネシウムとして 0.01 1\% 位含有されている.

"1 炭酸マグネシウムと塩基性炭酸マグネシウムの雨者を含めて，て てでは炭酸マグネシウムという，以下てれにしたがう。

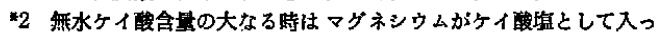
ているかる知れないが，こてでてういう場合を除外して教える。

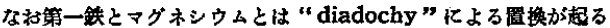
てとも考元られるので，一概にドロマイトか岸酸マグネシウムか と結論つけられない。が一般的机てう云えるであろう。

6) とのととに関しては昔から多数の論交がある。たと光ば最近では

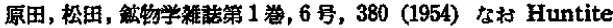

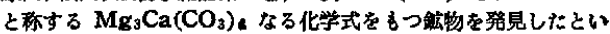
う報交があるが; とれは特例とみてよいであろう. G.T. Faust, Am. Mineralogist. 38, 4 (1953). 
的簡筆な場合について教察すればよい。

さて $\left[\mathrm{CaCO}_{3}\right]:\left[\mathrm{MgCO}_{3}\right]=1: 1$ なる炭酸カルシウム と炭酸マグネシウムの混合物と $\mathrm{CaMg}\left(\mathrm{CO}_{3}\right)_{2}$ のそれ ぞれの慜濁液に炭酸ガスを通す时に溶出されるイオンの

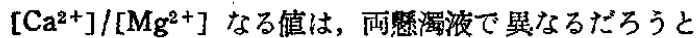
予想される。したがってあらかじめ孷酸カルシウムと $(\mathrm{Ca}, \mathrm{Mg}) \mathrm{CO}_{3}$ および炭酸カルシウムと炭酸マグネシウ ムの混合物を作り，乙の䀣濁液に炭竕ガスを通して溶出 される $\mathrm{Ca}^{2+}$ および $\mathbf{M g}^{2+}$ の量を知っておくととによ り微量マグネシウムの存在状態を決定できると思われ る。

\section{実験およびその結果}

\section{試薬}

炭酸カルシウム：特級品*る（万解石型）を用いた。自 然界の石灰石ははとんど方型石型であるからここでは方 解石型*4のものを用いる。

$\mathrm{CaMg}\left(\mathrm{CO}_{3}\right)_{2}$ ：純䊉なものを作ることか灘しいので天 然座のうち代表的なものと云われる栃木県营生産のド口 マイム*5を用いた。その化学組成は酸化カルシウム： $33.80 \%$ ，酸化マグネシウム $19.37 \%$ ，粘土：0.22\%で ある。

炭酸マグネシウム：自然界に存在する炭酸マグネシウ ムと同じものを人工的に作ることは難しいし，また天然 座の純䊉なものが入手できなかったので市股の盗基性湠

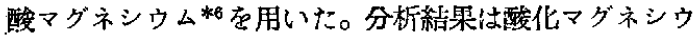
ム：44.2\%，灼熱娍量: $56.0 \%$ である。

\section{実験方法}

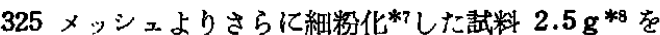
とり，蒸留水 $200 \mathrm{cc}$ に留濁させる。とれに大理石的 40

*3岑酸カルシウム中のマグネシウムの含量は酸化マグネシウムとし て $0.01 \%$ 以下であった. なおすぐ後で述べる実殹方法により赤 薬の炭酸カルシウム $2.5 \mathrm{~g}$ 支とり，溶出する $\mathrm{Mg}^{\mathrm{g}+}$ の量をオキ シム法によって定量した結果は $0.00003 \mathrm{~g} / 200 \mathrm{cc}$ 以下であっだ。

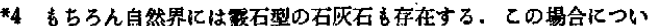
てはここではふれない。

*5 東大工学部, 永井彰一郎数授にいただく，てれはドロマイト $88 \%$ 方解石型岸酸カルシウム $12 \%$ になる。

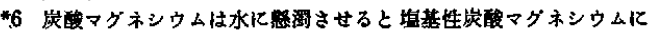
変化するととがしばしばあり，少なくとも塩基性炭酸、グネシウ ムの方が岸酸、グネシウムよりは安定である。よってててでは盐

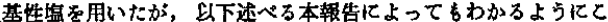

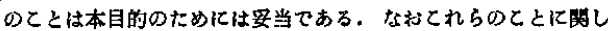

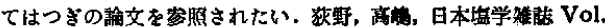
5, No. 2 No. 3 (16), 66 (1951); 村上, 石原, 同誌 Vol. 7, No. 1(26), 6(1953); 俄野, 同鿁 Vol. 8, No. 2(33), 66(1954); Vol. 8, No. 3 (34), 121 (1954) 等.

*7 325 メッシュ以下に細粷化する理由は本報文で後述する。

*8 マグネシウム含量がでく籊量の場合を取投うととが多いので便官

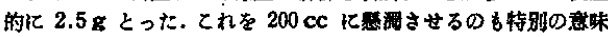
があるわけではない。 g 亿 $6 \mathrm{~N}$ 捣酸を徐々亿作用させて生ずる炭酸ガスを一旦 水洗し*9，約 25 分聞*9 通す。その後 10 分間*10 静置さ

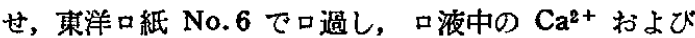
$\mathrm{Mg}^{2+}$ の量を测定する。 $\left[\mathrm{Ca}^{2+}\right]+\left[\mathrm{Mg}^{2+}\right]$ 注 E.D.T.A. 溶液による容量分析》で求め, $\mathrm{Ca}^{2+}$ はシュウ酸垛とし た後,過マンガン酸カリウム溶液による容量分析で求め， 俩者の差汃ら $\mathrm{Mg}^{2+}$ の量を䕗出する。

\section{結 果}

（1）それぞれ $325 \times ッ シ ェ$ 此下に細粉化した炭酸力 ルシゥムと㙂基性炭酸マダネシゥム，炭酸カルシウムと $\mathrm{CaMg}\left(\mathrm{CO}_{3}\right)_{2}$ および炭酸カルシウムと壏基性炭酸マグ ネシウムと $\mathrm{CaMg}\left(\mathrm{CO}_{3}\right)_{2}$ の湿合物について前述の力 法にしたがい，溶明した $\mathrm{Ca}^{2+}$ および $\mathrm{Mg}^{2+}$ の量を测 定した結果の一部をそれぞれ第 1 表，第 2 表および第 3 表に示す。とれらの結果から明らかなようにマグネシウ ムが酸酸マグネシウムとして入っている牌はマグネシウ 厶はその大部分か溶訨し*11, $\mathrm{CaMg}\left(\mathrm{CO}_{3}\right)_{2}$ として入って いる埸合はほとんどマグネシウムは搽出されないので武 料中のマグネシウムが雨者のいずれい形で存在している かは簡単にしかも明確に上記の方法で判定できる。てれ らの結果試料中のマグネシウムの含量と上記の方法によ る溶出液中の $\mathrm{Mg}^{2+}$ の量を知るととによって第 1 䒧, 第 2 表および第 3 表の結舁を参照すれば容易に石灰石中 の微量のマグネシウムの存在状態を知るととができる。 なお酸化マグネシウムとして $0.01 \%$ 位含有されている 昜合も判定が可能である。

（2）（1）項で示した $\mathrm{Ca}^{2+} お$ おび $\mathrm{Mg}^{2+}$ の溶田量

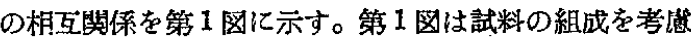

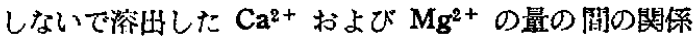
だけを示すものである。との図からわかるように上記の 方法による $\mathrm{Ca}^{2+}$ および $\mathbf{M g}^{2+}$ の溶圤量には明らかな 逆相関関係が存在する。

*9容易化誰にですでるようにというとと孝えて道す炭酸がスの

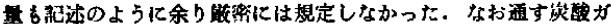

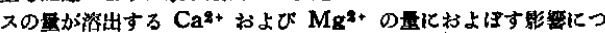
いては别報告する

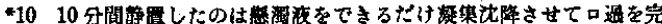

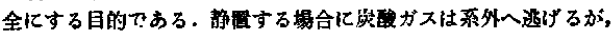

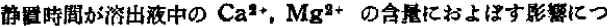
いては别に報告する。

7) 上野, 化学の矤域 5, No. 8, 57 (1951)

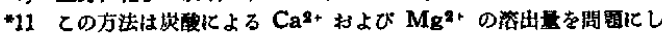

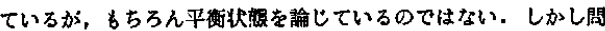

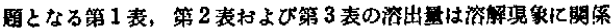
する因子に影整されることは明らかである。すなかち温度，通す

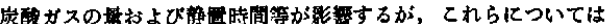
別䎲詳述する． $\mathrm{Mg}^{2+}$ が炭酸マグネシウムとして入っている場合 はマグネシウム合量が大になるはど，濯出する絬対量は大となる

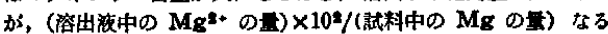
値は小となる。 


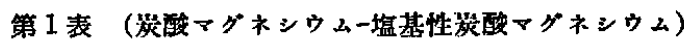

\begin{tabular}{|c|c|c|c|c|c|c|c|c|c|c|}
\hline \multirow[b]{2}{*}{ No. } & \multicolumn{2}{|c|}{ 試 } & \multirow[b]{2}{*}{$\underset{(\%)}{\mathrm{CaO}}$} & \multirow[b]{2}{*}{$\underset{(\%)}{\mathrm{MgO}}$} & \multicolumn{2}{|c|}{ 料 } & \multicolumn{2}{|c|}{ 溶出 } & \multicolumn{2}{|c|}{ 溶 出 比** } \\
\hline & $\begin{array}{c}\mathrm{CaCO}_{8} \\
(\mathrm{~g})\end{array}$ & $\begin{array}{c}\text { Mg-car- } \\
\text { bonate* } \\
(g)\end{array}$ & & & $\begin{array}{r}\mathrm{Ca} \\
(\mathrm{g})\end{array}$ & $\begin{array}{l}\mathbf{M g} \\
(\mathbf{g})\end{array}$ & $\begin{array}{c}\mathrm{Ca}^{2+} \\
(\mathrm{g} / 200 \mathrm{cc})\end{array}$ & $\begin{array}{c}\mathrm{Mg}^{2+* * *} \\
(\mathrm{~g} / 200 \mathrm{cc})\end{array}$ & $\begin{array}{c}\mathrm{Ca} \\
(\%)\end{array}$ & $\underset{(\%)}{\mathrm{Mg}}$ \\
\hline 1 & 2.00 & 0.50 & 44.7 & 10.6 & 0.800 & 0.155 & 0.043 & 0.060 & 5.4 & 39 \\
\hline 2 & 2.07 & 0.43 & 46.4 & 9.0 & 0.828 & 0.133 & 0.055 & 0.063 & 6.7 & 47 \\
\hline 3 & 2.25 & 0.25 & 50.4 & 5.3 & 0.900 & 0.077 & 0.065 & 0.048 & 7.2 & 62 \\
\hline 4 & 2.37 & 0.13 & 53.1 & 2.8 & 0.948 & 0.041 & 0.079 & 0.027 & 8.4 & 66 \\
\hline 5 & 2.40 & 0.10 & 53.8 & 2.1 & 0.960 & 0.031 & 0.072 & 0.021 & 7.5 & 68 \\
\hline 6 & 2.45 & 0.05 & 54.9 & 1.0 & 0.980 & 0.014 & 0.082 & 0.010 & 8.3 & 71 \\
\hline 7 & 2.48 & 0.02 & 55.6 & 0.4 & 0.992 & 0.0062 & 0.086 & 0.0050 & 8.6 & 80 \\
\hline 8 & 2.49 & 0.01 & 55.8 & 0.21 & 0.996 & 0.0031 & 0.087 & 0.0027 & 8.7 & 87 \\
\hline 9 & 2.495 & 0.005 & 55.9 & 0.10 & 0.998 & 0.0015 & 0.088 & 0.0014 & 8.8 & 93 \\
\hline 10 & 2.498 & 0.002 & 56.0 & 0.042 & 0.999 & 0.00062 & 0.089 & 0.0006 & 8.9 & 96 \\
\hline
\end{tabular}

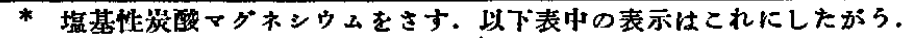

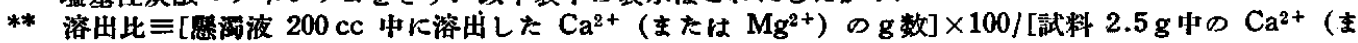
たは $\mathrm{Mg}^{2+}$ )のg数]. 以下表中の表示仕これにしたが5.

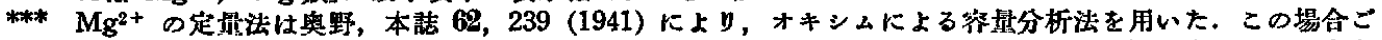
く微得の $\mathrm{Mg}^{2+}$ に対して $\mathrm{Ca}^{2+}$ 加多最共存子るので再沈殿を繰返えさないと $\mathrm{Mg}^{2+}$ の定最值は過大と なり，溶出比が $100 \%$ 以上になることがあるから必ず再沈成を 2 度綝返えさないといけない。このことは 本報交中のすいての実脸に必要なことである。

第 2 表 $\left(\mathrm{CaCO}_{3}-\mathrm{CaMg}\left(\mathrm{CO}_{3}\right)_{2}\right)$

\begin{tabular}{|c|c|c|c|c|c|c|c|c|c|c|}
\hline \multirow[b]{2}{*}{ No. } & \multicolumn{2}{|c|}{ 試 } & \multirow[b]{2}{*}{$\begin{array}{l}\mathrm{CaO} \\
(\%)\end{array}$} & \multirow[b]{2}{*}{$\begin{array}{c}\mathrm{MaO} \\
(\%)\end{array}$} & \multicolumn{2}{|c|}{ 料 } & \multicolumn{2}{|r|}{ 出罨 } & \multicolumn{2}{|c|}{ 溶 出 } \\
\hline & $\begin{array}{c}\mathrm{CaCO}_{3} \\
(\mathrm{~g})\end{array}$ & $\begin{array}{c}\mathrm{CaMg}- \\
\left(\mathrm{CO}_{3}\right)_{2} \\
(\mathrm{~g})^{2}\end{array}$ & & & $\begin{array}{c}\mathrm{Ca} \\
(\mathrm{g})\end{array}$ & $\begin{array}{l}\mathbf{M g} \\
(\mathbf{g})\end{array}$ & $\begin{array}{c}\mathrm{Ca}^{2+} \\
(\mathrm{g} / 200 \mathrm{cc}\end{array}$ & $\begin{array}{c}\mathrm{Mg}^{2+} \\
(\mathrm{g} / 200 \mathrm{cc})\end{array}$ & $\begin{array}{c}\mathrm{Ca} \\
(\%)\end{array}$ & $\begin{array}{l}\mathbf{M g} \\
(\%)\end{array}$ \\
\hline 1 & 0.29 & 2.21 & 33.8 & 19.4 & 0.603 & 0.292 . & 0.038 & 0.0040 & 6.3 & 1.5 \\
\hline 2 & 1.61 & 0.89 & 47.1 & 7.8 & 0.841 & 0.117 & 0.091 & 0.0010 & 10.9 & 0.9 \\
\hline 3 & 1.97 & 0.53 & 50.7 & 4.7 . & 0.904 & 0.070 & 0.099 & $0.0008_{0}$ & 10.9 & 1.1 \\
\hline 4 & 2.06 & 0.44 & 51.6 & 3.9 & 0.920 & 0.058 & 0.091 & $0.0004_{5}$ & 9.9 & 0.8 \\
\hline 5 & 2.23 & 0.27 & 53.3 & 2.3 & 0.951 & 0.035 & 0.098 & $0.0006_{0}$ & 10.3 & 1.7 \\
\hline 6 & 2.33 & 0.17 & 54.2 & 1.6 & 0.967 & 0.023 & 0.090 & $0.0003_{2}$ & 9.3 & 1.6 \\
\hline 7 & 2.39 & 0.11 & 54.9 & 0.93 & 0.980 & 0.014 & 0.100 & $0.0001_{6}$ & 10.2 & 1.1 \\
\hline 8 & 2.41 & 0.09 & 55.1 & 0.77 & 0.983 & 0.012 & 0.087 & $0.0001_{8}$ & 8.9 & 1.6 \\
\hline 9 & 2.46 & 0.044 & 55.6 & 0.39 & 0.991 & 0.0059 & 0.087 & $0.0001_{2}$ & 8.8 & 2.0 \\
\hline
\end{tabular}

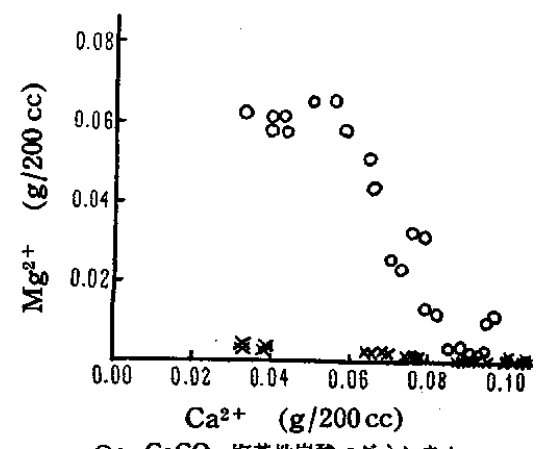

$\mathrm{O}: \mathrm{CaCO}_{3}$-㙁暮性炭酸マグネシウム $x: \mathrm{CaCO}_{3}-\mathrm{CaMg}\left(\mathrm{CO}_{3}\right)_{2}$

第 1 四
（3）上記の方法によりはぼ同一温度条件*12 で垁験 し，再現性を確かめた結果の一部を第 4 表に示す。との 結果加ら再現性はあると洘えてよい。

（4）試料の粒度がカルシウムおよびマグネシウムの 溶出量におよぼす影響を験した結果の一部を第 5 䒾に示 す。第 5 表では試薬闌に示した葛生産ドロマイトの場合 を示す。

この結果から試料の粒度は 325 メッシュ以下に細粉化

"12 温度が異なると $\mathrm{Ca}^{2+}$ および $\mathrm{Mg}^{2+}$ の溶出状能が翼なってくる。

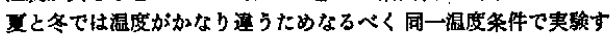
る必要がある．温度の影整については那化報告する。 
第 3 表 (炭酸カルシウムー $\mathrm{Mg}$-carbonate- $\left.\mathrm{CaMg}\left(\mathrm{CO}_{3}\right)_{2}\right)$

\begin{tabular}{|c|c|c|c|c|c|c|c|c|c|c|c|}
\hline \multirow[b]{2}{*}{ No. } & \multicolumn{2}{|c|}{ 試 } & \multirow[b]{2}{*}{$\begin{array}{c}\mathrm{CaMg} \\
\left(\mathrm{CO}_{8}\right)_{2} \\
(\mathrm{~g})\end{array}$} & \multirow[b]{2}{*}{$\begin{array}{l}\mathrm{CaO} \\
(\%)\end{array}$} & \multirow[b]{2}{*}{$\underset{(\%)}{\mathbf{M g O}}$} & \multicolumn{2}{|c|}{ 料 } & \multicolumn{2}{|c|}{ 出 } & \multirow{2}{*}{$\frac{\text { 溶 }}{\mathrm{Ca}}$} & \multirow{2}{*}{$\frac{\text { 比 }}{\underset{(\%)}{\mathrm{Mg}}}$} \\
\hline & $\begin{array}{c}\mathrm{CaCO}_{3} \\
(\mathrm{~g})\end{array}$ & $\begin{array}{c}\text { Mg-car- } \\
\text { bonate } \\
\text { (g) }\end{array}$ & & & & $\begin{array}{l}\mathrm{Ca} \\
(\mathrm{g})\end{array}$ & $\begin{array}{l}\mathrm{Ma} \\
(\mathrm{g})\end{array}$ & $\begin{array}{c}\mathrm{Ca}^{2+} \\
(\mathrm{g} / 200 \mathrm{cc})\end{array}$ & $\begin{array}{c}\mathrm{Mg}^{2+} \\
\mathrm{g} / 200 \mathrm{cc})\end{array}$ & & \\
\hline 1 & 0.301 & 0.500 & 2.149 & $27: 9$ & 24.0 . & 0.587 & 0.427 & 0.012 & 0.103 & 2.0 & 24.0 \\
\hline 2 & 0.245 & 0.500 & 1.755 & 26.8 & 24.9 & 0.479 & 0.375 & 0.0093 & 0.093 & 2.0 & 24.7 \\
\hline 3 & 0.305 & 0.100 & 2.185 & 32.2 & 20.3 & 0.596 & 0.317 & 0.025 & 0.026 & 4.1 & 8.2 \\
\hline 4 & 0.301 & 0.050 & 2.149 & 32.9 & 19.7 & 0.587 & 0.298 & 0.028 & 0.015 & 4.8 & 4.9 \\
\hline 5 & 0.245 & 0.050 & 1.755 & 32.7 & 19.9 & 0.479 & 0.246 & 0.025 & 0.013 & 5.1 & 5.1 \\
\hline 6 & 1.572 & 0.050 & 0.878 & 45.9 & 8.6 & 0.819 & 0.130 & 0.062 & 0.013 & 7.6 & 10.2 \\
\hline 7 & 2.011 & 0.050 & 0.439 & 50.4 & 4.8 & 0.900 & 0.072 & 0.062 & 0.013 & 6.9 & 17.9 \\
\hline 8 & 2.362 & 0.050 & 0.088 & 54.0 & 1.7 & 0.964 & 0.026 & 0.063 & 0.013 & 6.5 & 50.0 \\
\hline 9 & 2.406 & 0.050 & 0.044 & 54.4 & 1.3 & 0.972 & 0.020 & 0.064 & 0.013 & 6.6 & 61.9 \\
\hline 10 & 0.294 & 0.010 & 2.106 & 33.4 & 19.3 & 0.575 & 0.280 & 0.028 & 0.0069 & 4.9 & 2.5 \\
\hline 11 & 0.305 & 0.010 & 2.185 & 33.4 & 19.3 & 0.596 & 0.291 & 0.028 & 0.0066 & 4.8 & 2.3 \\
\hline 12 & 1.612 & 0.010 & 0.878 & 46.8 & 7.9 & 0.835 & 0.118 & 0.065 & 0.0035 & 7.8 & 2.9 \\
\hline 13 & 2.051 & 0.010 & 0.439 & 51.3 & 4.0 & 0.916 & 0.061 & 0.070 & 0.0029 & 7.7 & 4.8 \\
\hline 14 & 2.402 & 0.010 & 0.088 & 54.9 & 0.96 & 0.980 & 0.014 & 0.074 & 0.0020 & 7.6 & 13.8 \\
\hline 15 & 2.446 & 0.010 & 0.044 & 55.3 & 0.58 & 0.988 & 0.0086 & 0.074 & 0.0022 & 7.5 & 25.7 \\
\hline 16 & 1.618 & 0.005 & 0.878 & 46.9 & 7.8 & 0.837 & 0.117 & 0.065 & 0.0023 & 7.7 & 2.0 \\
\hline 17 & 2.056 & 0.005 & 0.439 & 51.4 & 3.9 & 0.918 & 0.059 & 0.068 & 0.0015 & 7.4 & 2.6 \\
\hline 18 & 2.407 & 0.005 & 0.088 & 55.0 & 0.86 & 0.982 & 0.013 & 0.073 & 0.00087 & 7.5 & 6.7 \\
\hline 19 & 2.451 & 0.005 & 0.044 & 55.4 & 0.48 & 0.990 & 0.0072 & 0.073 & 0.00079 & 7.4 & 10.9 \\
\hline
\end{tabular}

第 4 表

\begin{tabular}{|c|c|c|c|c|c|c|}
\hline 試 & 料 & (g) & 溶 出 & 揟 $\quad(g / 200 \mathrm{cc})$ & 溶 & 比 $(\%)$ \\
\hline $\mathrm{CaCO}_{3}$ & $\mathrm{Mg}$-carbonate & $\mathrm{CaMg}\left(\mathrm{CO}_{3}\right)_{2}$ & $\mathrm{Ca}^{2+}$ & $\mathbf{M g}^{2+}$ & $\mathrm{Ca}$ & $\mathbf{M g}$ \\
\hline 2.49 & 0.01 & - & 0.088 & 0.0027 & 8.8 & 87 \\
\hline " & " & - & 0.087 & 0.0028 & 8.7 & 90 \\
\hline " & " & - & 0.088 & 0.0028 & 8.9 & 90 \\
\hline " & " & - & 0.088 & 0.0029 & 8.9 & 93 \\
\hline 2.23 & - & 0.27 & 0.098 & $0.0006_{0}$ & 10.3 & 1.7 \\
\hline " & - & " & 0.099 & $0.0007_{0}$ & 10.4 & 2.0 \\
\hline " & - & " & 0.090 & $0.0006_{2}$ & 9.4 & 1.8 \\
\hline " & - & " & 0.090 & $0.0005_{6}$ & 9.4 & 1.6 \\
\hline
\end{tabular}

第 5 表

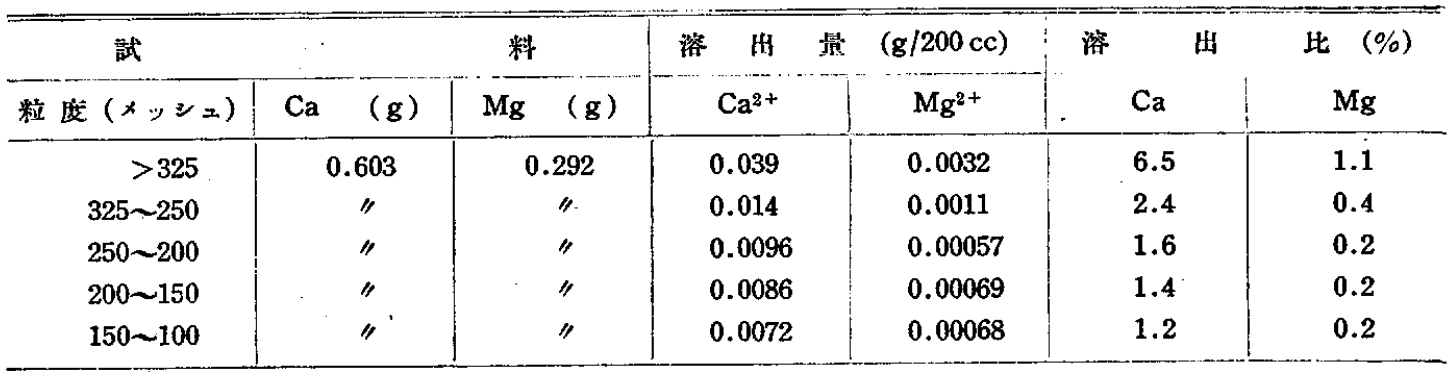


する必要のあるととが分る。

\section{總括}

（1）石灰石中に含まれるマグネシウムは一般には炭 酸マグネシウムかドロマイトとして入っていると考党て よい。

（2）両者の判定は 325 メッシュ以下に細粉化した武 料 $2.5 \mathrm{~g}$ を $200 \mathrm{cc}$ の蒸留水江緊濁させ,粎 $40 \mathrm{~g}$ の大理 石に $6 \mathrm{~N}$ 㙁酸を稌々に作用させて生ずる孷酸ガスる一 且水洗して, 約 25 分間照摆湤に通す。その後約 10 分 静置して東洋口紙 No.6 で口過し, 溶出液中の $\mathrm{Mg}^{2+}$ を定量する。あらかじめ試料中の $\mathbf{M g}^{2+}$ の量を測定し ておき, 溶出比を求める。一方試料の处理時と大体等 しい温度条件で種々のマグネシウム含量を示すような 炭酸カルシウムと炭酸マグネシウム, 炭酸カルシウムと $\mathrm{CaMg}\left(\mathrm{CO}_{3}\right)_{2}$ および炭酸カルシウムと炭酸マグネシウ ムと $\mathrm{CaMg}\left(\mathrm{CO}_{3}\right)_{2}$ とのそれぞれの混合物について上 記の方洗で溶出比を求めておす，乙の結果を試料の場合 と比較すると石灰石中のマグネシウムの存在状態を容易 に決定することができる。

最後に本実酸を行 $5 に$ 当 $\mathfrak{y}$ 種々御指導を睗わった北海 道大学理学部太秦康光教授, 東京工業大学岩岮岩次教授, 神户大学理学部土橋正二教授に厚く感謝する。な打試料 を睗わった東京大学工学部永开彰一郎教㥅に心から深謝 する。

（昭和 29 年 10 月, 日本化学会地球化学討論会溙演）

\section{（その 2） 存在状懸の新決定法の検討}

\section{緒言}

著者はすでに石㕄石中に微量含まれるマグネシウムの 存在状態の新決定法》を報告した。すなわち石灰石中の マグネシウムは一股的には炭酸マグネシウム*1 かドロマ イトとして入っていると考えられる。そてで武料の㗭濁 液に炭酸ガスを通して溶出する $\mathbf{M g}^{2+}$ の量を測定し，あ らかじめ武料中のマグネシウム含量を測定しておくとマ グネシウムの溶出比が分るが，ての值から簡単にマグネ シウムの存在状態を知るととができる。炭酸マグネシウ ムとして入っている場合は試料中のマグネシウムは大部 分溶出されるが，ドロマイトとして入っている場合はほ とんど容出されないからである。との方法は炭酸による

1) 北雺，本腾 77，211 (1956).

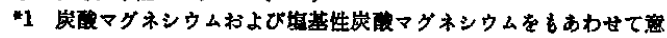
栋するととにする。
$\mathrm{Ca}^{2+}$ および $\mathrm{Mg}^{2+}$ の溶出量を問題にしているので溶 解現象に関保する因平は大きな 影響をもつと予想され ろ。との方法が再現性のあるととまた武料の粒度を 325 メッシュ上下に細粉化しなければならないとと等につい てはすでに報告りした。そこでての方法を確立するため と一方カルシウムおよびマグネシウムの溶出現象を詳細 に知るために，さらに溶解に影饗ある因子について検钨 したので得られた絈果について報告する。

\section{実験方法およびその結果}

すでに報告したようにマグネシウムがドロマイトとし て入っている場合は炭酸ガスによってマグネシウムはは とんど溶出されないが，炭酸マグネシウムとして入って いる埸合ははとんど大部分が溶出されてしまう。そてで とくに炭酸、グネシウムと炭酸カルシウムの湿合試料に ついてのみ溶解に影響する因子の榆討*2を行えばよいと 考えられる。

\section{実験方法}

すでに報告したように種々のマグネシウム含量を示す ような炭酸カルシウムと塩基性炭酸マグネシウム混合物 を 325 メッシュ以下に細粉化し，ての $2.5 \mathrm{~g}$ を $200 \mathrm{cc}$ の蒸留水に㲘濁させる。この愁濁液に炭酸ガスを普通は 25 分間通したあと 10 分間静置して東洋口紙 No.6 6 で 口過した口液中の $\mathrm{Ca}^{2+} お よ ひ ゙ ~ \mathrm{Mg}^{2+}$ の量を測定する。 $\left[\mathrm{Ca}^{2+}\right]+\left[\mathrm{Mg}^{2+}\right]$ は E.D.T.A. 溶液による容量分析 で求め, $\left[\mathrm{Ca}^{2+}\right]$ はシュウ酸塩としたあと過マンガン酸カ リウム溶液による容量分析により両者の差から $\left[\mathrm{Mg}^{2+}\right]$ を醇出する*。

\section{站 果}

上述の方法でとくに問題となる因子，すなわち温度， 通す㞸酸ガスの量および放置㭙間等について㮩討した結 果について述べる。

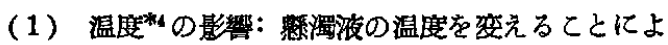

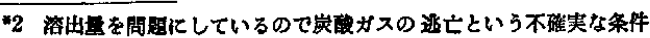

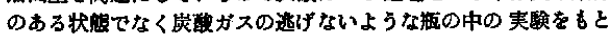

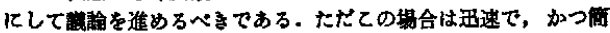

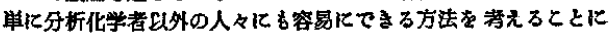
主眼をわいたてと叔よび宸酸ガスの逃失という不磪実な条俳です

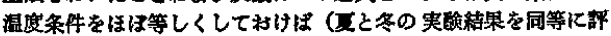
洒するととのないようにするとと)，再現性のある結果がえられだ ので(とれらの点は後还するのたが，岑酸ガのの逃失する炏蛅で

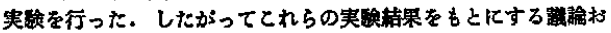

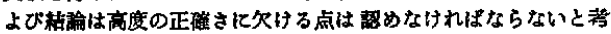
¿ている.

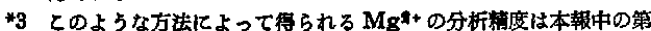

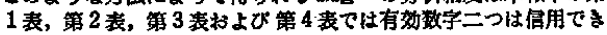
万.

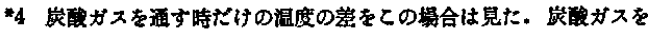

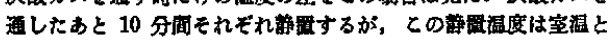
した. 